\title{
Knowledge and Rates of Use of Preschool Consultation by the Mothers in the Area of Health Tshitenge/Democratic Republic of Congo
}

\author{
Jean Christophe Bukasa Tshilonda ${ }^{1 *}$, Augustin Kadiata Bukasa ${ }^{1}$, Zelda Nkongolo Kitenge ${ }^{1}$, \\ Isaac Kalenda Ilunga ${ }^{1}$, Cedrick Ilunga Bimpa ${ }^{1}$, Jean Pierre Kufua Katukumbanyi ${ }^{2}$, \\ Dominique Kapitena Mangola ${ }^{2}$, Astrid Kabanga ${ }^{3}$, Benedicte Bileo4, Axel Ngoyis, \\ Therese Kapenga Mitanta ${ }^{5}$, Olivier Ejiba Nyongonyi ${ }^{5}$, Paulin Kabamba Lupueka ${ }^{5}$, \\ Alain Ngoyi Kibambe5, Jean Felix Kabangu6, Geremie Kazadi6, Alexis Ntambwe Mayombo7, \\ Andre Kazadi Mukendi ${ }^{1}$
}

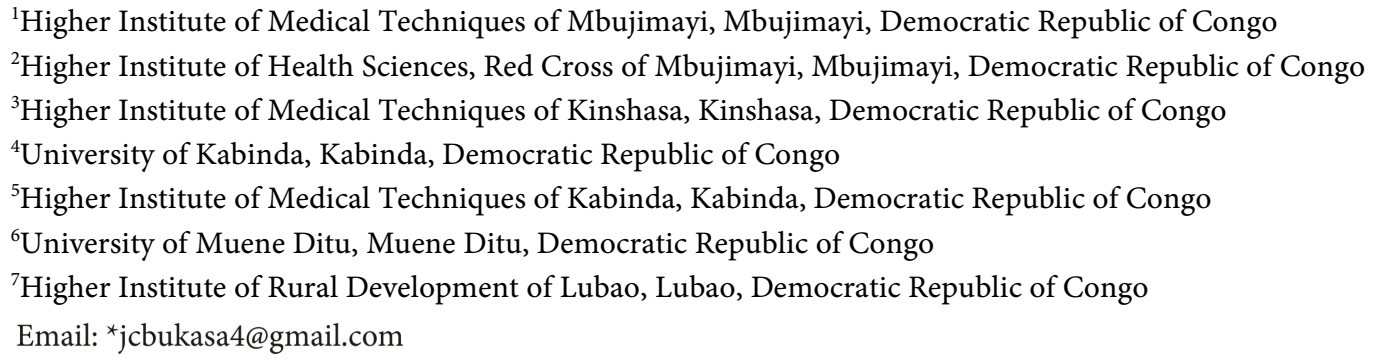

How to cite this paper: Tshilonda, J.C.B., Bukasa, A.K., Kitenge, Z.N., Ilunga, I.K., Bimpa, C.I., Katukumbanyi, J.P.K., Mangola, D.K., Kabanga, A., Bileo, B., Ngoyi, A., Mitanta, T.K., Nyongonyi, O.E., Lupueka, P.K., Kibambe, A.N., Kabangu, J.F., Kazadi, G., Mayombo, A.N. and Mukendi, A.K. (2019) Knowledge and Rates of Use of Preschool Consultation by the Mothers in the Area of Health Tshitenge/Democratic Republic of Congo. Open Access Library Journal, 6: e5064.

https://doi.org/10.4236/oalib.1105064

Received: November 22, 2018

Accepted: January 27, 2019

Published: January 30, 2019

\begin{abstract}
Introduction: The postponement of the preventive activities of the Provincial Division of Health of East Kasai 2016 revealed que le level of attendance of the preschool consultation is decreasing less and less in the Health Area Tshitenge. Thus, this study set the goal of determining the knowledge and use of maternal pre-school counseling in the Health Area Tshitenge. Methods. The survey method was used by means of a questionnary administered to mothers in this region, but more specifically, we collected data from 422 mothers responsible for randomly selected children aged 0 to 5 in the four health. Results. After analysis and analysis of the data with the computer tool, we obtained the following results: the rate of use of the preschool consultation service is $60.7 \%$; the level of education, occupation and the number of children under 5 years of age have a strong influence on the use of preschool counseling; lack of knowledge about the most important activity of preschool counseling has a negative influence on its use. There is a link
\end{abstract}


Copyright $\odot 2019$ by author(s) and Open Access Library Inc.

This work is licensed under the Creative Commons Attribution International License (CC BY 4.0).

http://creativecommons.org/licenses/by/4.0/ between the use of the preschool consultation and the most important activity of the preschool consultation for the respondent; there is also a link between this and an appointment on the map; and finally, the cost judgment of SPC strongly influences its use. Conclusion: In order to raise this activity, the revitalization of preschool consultation activities in the Tshitenge health area, the reinforcement of the parents' awareness on the use of preschool counseling from 0 to 59 months, and the revival of visits to homes for children whose mothers drop out of preschool counseling sufficient are a basis.

\section{Subject Areas}

Public Health

\section{Keywords}

Vaccination, Weight Curve, Weighing, Low Use, Preschool Consultation

\section{Introduction}

The growth and development in the physical, intellectual, psychological and social are the main characteristic of childhood [1] and depend largely on the quality of care provided to children in preschool. It therefore serves not only to assess the nutritional status and health of the child, but it is also an excellent measure of inequality of human development that people face [2].

Hence, the appropriate use of health services is important to the health improvement of the population especially in developing countries or economic, physical and social barriers exist. At the World Summit for Children, the international community has set itself the goal of promoting growth and its regular monitoring to be institutionalized in all countries in the late 1990s [3].

For its part, Ngandu [4] states that assessing regular growth is the most direct way to detect disturbances in the health of this fragile; and also an essential preventive measure to decrease morbidity and mortality in childhood.

The observation was made that, after the last vaccination against measles and yellow fever (around the ninth month), very few children come to the SPC, while it should continue up to 5 years. Indeed, it is at this age that the child malnutrition begins to manifest, as that causes the slowdown in growth and mental problems, especially in children 0 to 5 years from hearing school performance [5]. Also it is from this age that on the one hand, breastfeeding goes to his removal, the child walks, talks, develops contact and sociability acquires independence, on the other hand the mother of pregnant again, so it's at that age where malnutrition begins to manifest the most.

The determination of the risk faced children who drop out early SPC is higher in the age group of 24 to 34 months for acute malnutrition and underweight, and in that of 36 to 47 months for chronic malnutrition according to study in the health zone of Kisenso [4]. This malnutrition will have serious 
repercussions on health, their future development and that of society. In the absence of any intervention, these malnourished children are vulnerable to infections, deficiency diseases, neurological disabilities, and even death.

According to L'wed, use of SPC is still a public health problem in developing countries, and it is found that many children do not regularly attend the SPC activities. Therefore 1 child out of 22 dies in its first two years. This represents 6.2 million deaths of children under 5 years old in a year [6].

UNICEF also confirms that the use of SPC still poses serious problems in the developing countries and especially in very remote areas, it is that more children under 5 years do not regularly follow the CPS Service and the likely causes in approximately $78.7 \%$ are: sufficient knowledge, literacy, multiparity, early pregnancy, negligence, various jobs for women, non-involvement of men in promotional services [7].

The report of the preventive activities of the Provincial Health Division of Kasai Oriental in 2016 has revealed that the level of attendance at the pre consultation is less shrinking Tshitenge in the health area.

Based on the foregoing, we asked the questions of mothers of Tshitenge health zone, do they have sufficient knowledge about the preschool consultation? What is the rate of use of this pre-consultation service?

\section{Material and Methods}

\subsection{Design}

Our study is a prospective cross-sectional survey which has the advantage of allowing to collect, at the same time, information on various health events.

\subsection{Method}

The investigation by a questionnaire, was the used in this study and allowed us to collect donnéesnécessaires with mothers of children aged 0 to 5 years.

\subsection{The Study Site}

The study was conducted in four health areas of Tshitenge health zone.

\subsection{Study Population}

The study population consists of mothers with children aged 0 to 5 years in their households.

\subsection{Sample}

It is 422 mothers randomly selected from four of the area health areas. SPSS has enabled the analysis of data using the chi-square of Pearson (Khi2) to compare and test the statistical significance.

\subsection{Data Sources}

As indicated below each table, all collected data to source our surveys of mothers. 


\section{Results}

\subsection{Results of Descriptives Analyzes}

The data in Table 1 show that on household occupation represent $49.5 \%$. The distribution of the sample according to the ages of children under 5 years indicates that the most represented age group is between 12 to 23 months (28, 9\%) followed by 0 to 11 month $25.8 \%$ and that of 24 to 35 months with $18.0 \%$. Regarding the educational level of subjects of study, the majority (33.2\%) have completed secondary studies unfinished, 27.7\% A primary level, $18.2 \%$ Have completed secondary level education.For the number of children under 5 years, households in 1 (A) to 3 children represent $67.3 \%$.Regarding the sex of children under 5 years, $57.1 \%$ were female with a sex ratio of 0.75 .

Table 2 indicates that the knowledge of the age of onset of SPC at birth is $46.7 \%$.

Regarding the knowledge related to the age where SPC must stop, $37.9 \%$ of mothers surveyed said that at birth to 8 months, $26.1 \%$ at 2 years and $19.2 \%$ at 1 year. Regarding the knowledge of the importance of CPS vaccination is $32.2 \%$, followed by $21.1 \%$ nutrition and weighing $17.1 \%$. Knowledge of the activities taking place at SPC: vaccination $30.3 \%$, appointments securing the $26.8 \%$ and $19.4 \%$ weighed. $76.8 \%$ of mothers answered that the most important activity of the SPC is vaccination.

Table 3 indicates that $60.7 \%$ of the mothers surveyed reported having attended SPC during the last three months.Regarding the reason for the consultation SPC, vaccination represents $44.5 \%, 22.7 \%$ weighing and monitoring of growth $18.8 \%$. As for the time of day when the CPS is organized $97.4 \%$ answered before noon. Time spent SPC most represented is less than one hour (68.5\%), 100\% of mothers reported they pay $100 \mathrm{FC}$ and 100 per session, $72.7 \%$ had an SPC card and the appointment was noted on the plug at $74.6 \%$.

\subsection{Results of Bivariate Analyzes}

Table 4 indicates there is an association between the use of SPC and some socio-cultural characteristics of mothers such as the level of education $(\mathrm{p}=$ $0.002)$, the profession $(P=0.000)$ and the number of children under 5 years in the household $(\mathrm{p}=0.028)$.

In Table 5, There is no significant link between the use of SPC and the knowledge of the age of onset SPC knowledge related to the age where SPC must stop, knowledge the importance of CPS, knowledge of the activities taking place at SPC. By cons there is a link between the use of SPC and the most important activity of SPC for the respondent ( $\mathrm{p}=0.043)$.

In Table 6, the time of day when the CPS is organized, spent time at SPC and the fact of having a listing of SPC are not statistically associated with the use of SPC, but there a connection between this and having a go on the card $(\mathrm{p}=$ 0.001) (Table 5). 


\section{Discussion}

The data in Table 1 show that the household Occupation is $49.5 \%$. The distribution of the sample according to the ages of children under 5 years indicates that the most represented age group is between 12 to 23 months (28, 9\%) followed by 0 to 11 month $25.8 \%$ and that of 24 to 35 months with $18.0 \%$. Regarding the educational level of subjects of study, the majority (33.2\%) have completed secondary studies unfinished, 27.7\% Primary level, $18.2 \%$ have completed secondary level education.

Table 1. Distribution of respondents according to the socio-cultural.

\begin{tabular}{cccc}
\hline Characteristics & Categories & $\mathrm{n}=422$ & $\%$ \\
\hline \multirow{2}{*}{ Study level } & No & 64 & 15.2 \\
& Primary & 117 & 27.7 \\
& Secondary unfinished & 140 & 33.2 \\
& Secondary completed & 77 & 18.2 \\
& Graduated & 10 & 2.4 \\
Profession & Graduated & 14 & 3.3 \\
& A pupil or student & 98 & 23.2 \\
Number of children under 5 years & Household & 209 & 49.5 \\
& Informal sector & 66 & 15.6 \\
& Public sector & 49 & 11.6 \\
Ages of children under 5 years & A 3 children & 284 & 67.3 \\
& 0 to 11 months & 109 & 32.7 \\
& 12 to 23 months & 122 & 28.9
\end{tabular}

Source: our field investigations.

Table 2. Distribution of respondents by knowledge of SPC.

\begin{tabular}{cccc}
\hline Characteristics & Categories & $\mathrm{n}=422 \%$ \\
\hline Knowledge of the age of onset of SPC & At birth & 197 & 46.7 \\
& 1 month & 119 & 28.2 \\
& At 2 months & 72 & 17.1 \\
& 3 months & 9 & 2.1 \\
Knowledge related to the age where SPC must & To 4 months & 19 & 4.5 \\
stop & At birth to 8 months & 160 & 37.9 \\
& At 9 months & 64 & 15.2 \\
& 1 year & 81 & 19.2 \\
& 2 years & 110 & 26.1 \\
\hline
\end{tabular}




\section{Continued}

\begin{tabular}{|c|c|c|c|}
\hline \multirow{6}{*}{ Knowledge of the importance of CPS } & Growth monitoring & 73 & 17.3 \\
\hline & $\begin{array}{l}\text { Monitoring of } \\
\text { nutritional status }\end{array}$ & 89 & 21.1 \\
\hline & The vaccination & 136 & 32.2 \\
\hline & The weighing & 72 & 17.1 \\
\hline & Disease & 52 & 12.3 \\
\hline & The weighing & 82 & 19.4 \\
\hline \multirow{3}{*}{ Knowledge of activities taking place at SPC } & Physical examination & 44 & 10.4 \\
\hline & The vaccination & 128 & 30.3 \\
\hline & $\begin{array}{c}\text { Health and nutrition } \\
\text { education }\end{array}$ & 55 & 13.0 \\
\hline \multirow{3}{*}{$\begin{array}{l}\text { The most important activity of SPC for the } \\
\text { respondent }\end{array}$} & Fixing appointments & 113 & 26.8 \\
\hline & Other & 98 & 23.2 \\
\hline & Vaccination & 324 & 76.8 \\
\hline
\end{tabular}

Source: our field investigations.

Table 3. Distribution of respondents according to the use of pre-service.

\begin{tabular}{|c|c|c|c|}
\hline Characteristics & Categories & \multicolumn{2}{|c|}{$\mathrm{n}=422 \%$} \\
\hline \multirow{4}{*}{$\begin{array}{l}\text { Having attended SPC } \\
\text { during the last three months }\end{array}$} & Yes & 256 & 60.7 \\
\hline & No & 166 & 39.3 \\
\hline & The growth monitoring & 48 & 18.8 \\
\hline & $\begin{array}{l}\text { The monitoring of } \\
\text { nutritional status }\end{array}$ & 14 & 5.5 \\
\hline \multirow[t]{4}{*}{ Reason for consultation SPC } & $\begin{array}{c}\text { The monitoring of the } \\
\text { health status }\end{array}$ & 21 & 8.2 \\
\hline & The vaccination & 114 & 44.5 \\
\hline & The weighing & 58 & 22.7 \\
\hline & Disease & 1 & 0.4 \\
\hline \multirow{2}{*}{ Time of day when the CPS is organized } & Before noon & 411 & 97.4 \\
\hline & Afternoon & 11 & 2.6 \\
\hline \multirow{2}{*}{ Time spent on SPC } & Less than an hour & 289 & 68.5 \\
\hline & An hour and more & 133 & 31.5 \\
\hline \multirow{2}{*}{ Number of money paid per session } & Nothing at all & 0 & 0 \\
\hline & $100 \mathrm{FC}$ and more & 422 & 100 \\
\hline \multirow[b]{2}{*}{ Having a listing of SPC } & Yes & 307 & 72.7 \\
\hline & No & 115 & 27.3 \\
\hline \multirow[t]{2}{*}{ See an appointment on the plug } & Yes & 315 & 74.6 \\
\hline & No & 107 & 25.4 \\
\hline
\end{tabular}

Source: our field investigations. 
Table 4. Association between the sociocultural characteristics of respondents and the use of SPC.

\begin{tabular}{|c|c|c|c|c|c|}
\hline \multirow{3}{*}{$\begin{array}{l}\text { Characteristics } \\
\qquad(\mathrm{N}=422)\end{array}$} & \multicolumn{2}{|c|}{ Using SPC } & \multirow{3}{*}{$\mathrm{X} 2$} & \multirow{3}{*}{$\mathrm{P}$} & \multirow{3}{*}{$S$} \\
\hline & Yes & no & & & \\
\hline & $\mathrm{n}=256$ & $\mathrm{n}=166$ & & & \\
\hline \multicolumn{6}{|l|}{ Study level } \\
\hline $\begin{array}{c}\text { No, primary and } \\
\text { secondary unfinished }\end{array}$ & 182 & 139 & 8.83 & 0,002 & $S$ \\
\hline Secondary and higher completion & 74 & 27 & & & \\
\hline \multicolumn{6}{|l|}{ Profession } \\
\hline Household & 176 & 139 & 11.9 & 0.000 & $S$ \\
\hline Other professions & 80 & 27 & & & \\
\hline \multicolumn{6}{|l|}{ Number of children under 5 years } \\
\hline Less than 4 children & 162 & 122 & 4.7 & 0.028 & $S$ \\
\hline 4 more children & 94 & 44 & & & \\
\hline \multicolumn{6}{|l|}{ Ages of children under 5 years } \\
\hline 0 to 23 months & 111 & 80 & 0.94 & 0.329 & NS \\
\hline 24 months and 59 months & 145 & 86 & & & \\
\hline \multicolumn{6}{|l|}{ Gender of children under 5 years } \\
\hline Male & 115 & 66 & 1.09 & 0.295 & NS \\
\hline Female & 141 & 100 & & & \\
\hline
\end{tabular}

Source: our field investigations.

Table 5. Links between knowledge of SPC and its use.

\begin{tabular}{|c|c|c|c|c|c|}
\hline \multirow{3}{*}{$\begin{array}{l}\text { Characteristics } \\
\qquad(\mathrm{N}=422)\end{array}$} & \multicolumn{2}{|c|}{ use } & \multirow{3}{*}{$\mathrm{X} 2$} & \multirow{3}{*}{$\mathrm{P}$} & \multirow{3}{*}{$S$} \\
\hline & Yes & No & & & \\
\hline & $\mathrm{n}=256$ & $n=166$ & & & \\
\hline \multicolumn{6}{|l|}{$\begin{array}{l}\text { Knowledge of } \\
\text { the age of onset SPC }\end{array}$} \\
\hline Knows (at birth) & 140 & 85 & 0.49 & 0.483 & NS \\
\hline Do not know (other city age) & 116 & 81 & & & \\
\hline \multicolumn{6}{|l|}{$\begin{array}{l}\text { Knowledge related to the age } \\
\text { where SPC must stop }\end{array}$} \\
\hline Knows (5 years) & 183 & 122 & 0.20 & 0.652 & NS \\
\hline Do not know (other city age) & 73 & 44 & & & \\
\hline \multicolumn{6}{|l|}{$\begin{array}{l}\text { Knowledge of the } \\
\text { importance of CPS }\end{array}$} \\
\hline $\begin{array}{l}\text { Good knowledge } \\
\text { (more than } 3 \text { magnitudes cited) }\end{array}$ & 174 & 124 & 2.19 & 0.138 & NS \\
\hline $\begin{array}{c}\text { Poor knowledge } \\
\text { (3 months magnitudes cited) }\end{array}$ & 82 & 42 & & & \\
\hline
\end{tabular}




\section{Continued}

\begin{tabular}{|c|c|c|c|c|c|}
\hline \multicolumn{6}{|l|}{$\begin{array}{c}\text { Knowledge of activities taking } \\
\text { place at SPC }\end{array}$} \\
\hline $\begin{array}{l}\text { Good knowledge } \\
\text { (all the above activities) }\end{array}$ & 132 & 80 & 0.45 & 0.498 & NS \\
\hline $\begin{array}{c}\text { Poor knowledge } \\
\text { (within } 3 \text { above activities) }\end{array}$ & 124 & 86 & & & \\
\hline \multicolumn{6}{|l|}{$\begin{array}{l}\text { The most important activity of } \\
\text { SPC for the respondent }\end{array}$} \\
\hline $\begin{array}{l}\text { Vaccination and health and } \\
\text { nutrition education }\end{array}$ & 68 & 30 & 4.07 & 0.043 & $S$ \\
\hline $\begin{array}{l}\text { Weighing, physical } \\
\text { examination and other }\end{array}$ & 188 & 136 & & & \\
\hline
\end{tabular}

Source: our field investigations.

Table 6. Links between certain characteristics related to organization of the SPC service and use of SPC.

\begin{tabular}{|c|c|c|c|c|c|}
\hline \multirow{3}{*}{$\begin{array}{l}\text { Characteristics } \\
\qquad(\mathrm{N}=422)\end{array}$} & \multicolumn{2}{|c|}{ Using SPC } & \multirow{3}{*}{$\mathrm{X} 2$} & \multirow{3}{*}{$\mathrm{P}$} & \multirow{3}{*}{$S$} \\
\hline & Yes & No & & & \\
\hline & $\mathrm{n}=256$ & $n=166$ & & & \\
\hline \multicolumn{6}{|l|}{$\begin{array}{l}\text { Time of day when } \\
\text { the CPS is organized }\end{array}$} \\
\hline Before noon & 249 & 162 & 0.04 & 0.837 & NS \\
\hline Afternoon & 7 & 4 & & & \\
\hline \multicolumn{6}{|l|}{ Time spent on SPC } \\
\hline Less than an hour & 86 & 47 & 1.30 & 0.254 & NS \\
\hline An hour and more & 170 & 119 & & & \\
\hline \multicolumn{6}{|c|}{ Having a listing of SPC } \\
\hline Yes & 182 & 125 & 0.89 & 0.342 & NS \\
\hline no & 74 & 41 & & & \\
\hline \multicolumn{6}{|c|}{ See an appointment on the plug } \\
\hline Yes & 177 & 138 & 10.41 & 0,001 & $s$ \\
\hline No & 79 & 28 & & & \\
\hline
\end{tabular}

Source: our field investigations.

For the number of children under 5 years, households in 1 (A) to 3 children represent $67.3 \%$. Regarding the sex of children under 5 years, $57.1 \%$ were female with a sex ratio of 0.75 . Our results differ from those of Kasole who revealed in his study that the majority of mothers had, $40 \%$ had a level primary study [8]. By cons they approach Kamwasha Katonga who observed that 33.6\% had a level of unfinished secondary study [5].

Table 2 indicates that the knowledge of the age when SPC begins at birth is 
46.7\%. Regarding the knowledge related to the age where SPC must stop, $37.9 \%$ of mothers interviewed told from birth to 8 months, $26.1 \%$ at 2 years and $19.2 \%$ at 1 year.

Regarding the knowledge of the importance of CPS vaccination is $32.2 \%$, followed by $21.1 \%$ nutrition and weighing $17.1 \%$. Knowledge of the activities taking place at SPC: vaccination $30.3 \%$, appointments securing the $26.8 \%$ and 19.4\% weighed. $76.8 \%$ of mothers answered that the most important activity of the SPC is vaccination.

According to Table 3, 60.7\% of the mothers surveyed reported having attended SPC or during the last three months. Regarding the reason for the consultation SPC vaccination is $44.5 \%, 22.7 \%$ weighing and monitoring of growth $18.8 \%$.

As for the time of day when the CPS is organized $97.4 \%$ answered before noon. Time spent SPC most represented is less than one hour (68.5\%), 100\% of mothers reported they pay 100 FC and 100 per session, $72.7 \%$ had an SPC card. The appointment was noted on the card at $74.6 \%$.

According to Table 3, there is no association between the use of SPC age of children under 5 years and sex of children under 5 years. By cons, there is a statistically significant link between the level of education $(p=0.002)$, the profession $(P=0.000)$, the number of children under 5 years $(P=0.028)$. These results are consistent with one hand a study of the Democratic Republic of Congo on Causes of low utilization of pre-consultation service in urban areas. If the Kamalondo health zone, conducted by Kamwasha Katonga which revealed an association between socio-demographic characteristics (level of education and profession mothers) on one hand and the reasons for non-attendance at least for preschool consultation 'somewhere else ; there was a link is significant with the profession against it is not significant to the level of study [5].

While in Rwanda, a prospective study by Munyamahoro and Ntaganira in the district From Rubavu, showed that the use of health services by households, including the pre-consultation was based on various factors related to both the individual (age, sex, level of education of the household head ...) and in the [1] [4] [9] [10] environment.

In view of Table 5, there is no significant link between the use of SPC and the knowledge of the age when the early SPC knowledge related to the age where SPC has to stop, the knowledge of the importance of the SPC, knowledge of the activities taking place at SPC. By cons there is a link between the use of SPC and the most important activity of SPC for the respondent ( $\mathrm{p}=0.043)$.

Table 6 reveals that the time of day when the CPS is organized, time SPC and having a listing of SPC are not statistically associated with the use of SPC, but there a connection between this and having a go on the card $(p=0.001)$.

\section{Conclusion}

To achieve higher level of knowledge and further increase the utilization rate of preschool consultation, it should raise awareness of mothers on the use of 
preschool consultation even after completion of the immunization schedule for children 0 to 59 months, the revival of home visits for children whose mothers give preschool consultation a sufficient basis. For this, we suggest that the CPS in general and especially the growth of surveillance, continues steadily to 59 months. Thus, officials of Health Provincial Division must revitalize the activities of the pre-consultation in Tshitenge Health Zone.

\section{Acknowledgements}

We thank all the authors who read and made necessary corrections to improve scientifically and shape this article.

\section{Conflicts of Interest}

The authors declare no conflicts of interest regarding the publication of this paper.

\section{References}

[1] Parkin and Stanfield, P. (2001) Growth and Development. In: Stanfield, P., Brueton M., Chan, M., Parkin, M. and Waterstone, T., (Eds.), Diseases of Children in the Tropics and Subtropics, ELST, London, 7-13.

[2] Onys Million Frongillo, E.A. and Blossner, M. (2001) Is Malnutrition Declining? Analysis of the Evolution of Child Malnutrition Since 1980. Bulletin of the World Health Organization: The International Journal of Public Health, 78, 1222-1233.

[3] Luboya, O. (2010) Health Service Organization, Notes. School of Public Health. UNILU. Academic Year, 31-43.

[4] Ngandu, D., Okitolonda, W. and Kayembe, K.P. (2007) Attendance of Preschool Consultation in Kisenso Health Zone. Medical Congo, 4, 32-38.

[5] Katonga, K. (2009) Causes of Low Utilization of Pre-Consultation Service in Urban Areas. If the Kamalondo Health Zone in the DRC, University of Lubumbashi, Unpublished, 45-67.

[6] Wed (2010) Social Factors of Non-Use of Antenatal and Postnatal Services or Their Misuse in Ivory Coast. African Evaluation Journal, 2, 12 p. https://doi.org/10.4102/aej.v2i1.79

[7] UNICEF (2011) The Preschool Reference Guide, PRONANUT/UNICEF, Kinshasa, 45.

[8] Kasole, L. (2000) Identification Testing of Determinants of Access to Health Care in the Health Zone of Ngaba, Memory, Faculty of Economics/UNIKIN, 67-75.

[9] Munyamahoro and Ntaganira (2012) Determinants of Use of Health Services by Households in the Rubavu District in Rwanda. Medical Journal/ Rwandan Medical Journal, 69, 12-17.

[10] Ngandu, H.G. (2002) About Monitoring the Growth of Children 0 - 5 Years in the CITy of Kinshasa. Medical Congo, 3, 5-7. 